\title{
Hubungan Profil Lipid dan Kadar High-Sensitivity C-Reactive Protein dengan Outcome Pasien Stroke Iskemik Akut
}

\author{
Stefanus Erdana Putra ${ }^{1}$, Fauzi Novia Isnaening Tyas ${ }^{1}$, Muhammad Hafizhan ${ }^{1}$, \\ Raden Ajeng Hanindia Riani Prabaningtyas ${ }^{1}$, Diah Kurnia Mirawati ${ }^{1}$ \\ KSM Ilmu Penyakit Saraf Fakultas Kedokteran Universitas Sebelas Maret
}

Korespondensi : stefanuserdanaputra@gmail.com

\begin{abstract}
ABSTRAK
Pendahuluan: Stroke adalah penyebab utama kecacatan jangka panjang dengan dampak klinis dan sosial ekonomi yang signifikan di seluruh dunia. Hiperlipidemia dan inflamasi memainkan peranan penting dalam patofisiologi stroke iskemik. Meskipun high-sensitivity C-Reactive Protein (hs-CRP) dan kadar lipid merupakan penentu risiko penyakit pembuluh darah, kekuatan penggunaan biomarker ini dalam penentuan prognosis stroke iskemik belum dapat dipastikan. Penelitian ini bertujuan untuk mengetahui hubungan kadar hs-CRP dan profil lipid pada pasien stroke iskemik akut dan memahami hubungan antara biomarker tersebut dengan outcome jangka pendek.

Metode penelitian: Penelitian cross-sectional dilakukan pada 34 pasien dengan serangan stroke iskemik pertama kali. Profil lipid dan hs-CRP diukur pada hari pertama masuk rumah sakit. Defisit neurologis diukur menggunakan National Institutes of Health Stroke Scale (NIHSS) dan outcome diukur menggunakan Barthel Index pada hari ke-7 perawatan di unit stroke. Selanjutnya, kadar serum hs-CRP dan profil lipid dianalisis korelasinya dengan defisit neurologis dan outcome jangka pendek.

Hasil penelitian: Pasien stroke iskemik memiliki kadar hs-CRP, kolesterol total (TC), trigliserida (TG), low-density lipoprotein (LDL) yang lebih tinggi; serta kadar high-density lipoprotein (HDL) yang lebih rendah dari kriteria normal. Berdasarkan uji korelasi Pearson, LDL memiliki korelasi signifikan dengan NIHSS ( $r=0,447 ; \mathrm{p}=0,008)$ sedangkan hs-CRP memiliki korelasi signifikan yang lebih kuat dengan Barthel Index daripada NIHSS ( $\mathrm{r}=$ 0,412; $\mathrm{p}=0,015)$. TC dan HDL juga memiliki korelasi signifikan dengan NIHSS.

Kesimpulan: Penelitian ini menunjukkan bahwa profil lipid dan hs-CRP dapat digunakan sebagai prediktor prognosis outcome stroke iskemik akut.

Kata kunci: Barthel Index, C-Reactive Protein, National Institutes of Health Stroke Scale, profil lipid, stroke iskemik
\end{abstract}

\begin{abstract}
Introduction: Stroke is the leading cause of long-term disability with significant clinical and socioeconomic impact worldwide. Hyperlipidemia and inflammation play major roles in ischemic stroke. While high-sensitivity C-Reactive Protein (hs-CRP) and lipid levels are established risk determinants for vascular disease, the relative strength of these biomarkers for ischemic stroke is uncertain. The purpose of this study is to investigate the association of hs-CRP levels and lipid profile in acute ischemic stroke patients and understand correlation between those markers and short-term outcome.

Methods: This was a cross-sectional study of 34 first-timer ischemic stroke patients. Lipid profiles and hs-CRP were measured on admission day. The neurological deficit was quantified using National Institutes of Health Stroke Scale (NIHSS) and outcome was quantified using Barthel Index at the $7^{\text {th }}$ day in stroke unit. Serum level of hs-CRP and lipid profile were estimated and correlated with neurological deficit and short-term outcome.
\end{abstract}


Results: Ischemic stroke patients had higher levels of hs-CRP, total cholesterol (TC), triglyceride (TG), low-density lipoprotein (LDL); and lower level of high-density lipoprotein (HDL) than normal criteria. Based on Pearson correlation test, LDL had significant correlation with NIHSS ( $r=0.447 ; p=0.008)$ while $h s-C R P$ had stronger significant correlation with Barthel Index than NIHSS $(r=-0.412 ; p=0.015) . T C$ and HDL also had significant correlation with NIHSS.

Conclusions: This research suggests that lipid profile and hs-CRP can be used as predictors of prognosis for acute ischemic stroke outcome.

Keywords: Barthel index, C-reactive protein, National Institutes of Health Stroke Scale, lipid profile, ischemic stroke

\section{PENDAHULUAN}

Stroke merupakan penyakit berupa gangguan fungsional otak fokal maupun general secara akut yang terjadi lebih dari 24 jam. Stroke menyerang saat pembuluh darah yang membawa oksigen dan nutrisi ke otak tersumbat atau pecah. Saat hal tersebut terjadi, terdapat bagian otak yang tidak mendapat nutrisi dan oksigen, sehingga dapat terjadi proses kematian sel otak ${ }^{1}$. Terdapat dua jenis stroke, yaitu stroke iskemik dimana adanya sumbatan di pembuluh darah, dan stroke hemoragik dimana pembuluh darah otak pecah. Menurut Kementerian Kesehatan Republik Indonesia, prevalensi penyakit stroke di Indonesia meningkat dari 7 per 1000 penduduk pada tahun 2013 menjadi 10,9 per 1000 penduduk pada tahun $2018^{2}$. Sebagian besar kejadian stroke tersebut merupakan stroke iskemik ${ }^{3}$.

Stroke memiliki beberapa faktor risiko. Faktor risiko stroke meliputi hipertensi, usia di atas 50 tahun, peningkatan kolesterol total, serta peningkatan gula darah. Pada penelitian Dinati et al. di Sumatera Barat, $69,79 \%$ pasien stroke mengalami peningkatan kadar kolesterol total ${ }^{3}$. Peningkatan kadar kolesterol total dapat menyebabkan aterosklerosis yang dapat menyebabkan tersumbatnya pembuluh darah. Salah satu proses yang berperan pada pembentukan aterosklerosis adalah proses inflamasi. Highsensitivity $C$-reactive protein (hs-CRP) merupakan protein fase akut yang diproduksi oleh hepar yang akan meningkat pada kondisi inflamasi ${ }^{4}$. Hs-CRP banyak digunakan sebagai penanda stroke akut. Peningkatan kadar hsCRP berhubungan dengan stroke iskemik dan beberapa penelitian juga menunjukkan hubungan yang sama pada stroke hemoragik ${ }^{5}$.

Stroke merupakan penyebab tertinggi kecacatan kronik kelompok umur di atas 45 tahun. Disabilitas akibat stroke menyebabkan hilangnya produktivitas dan menyebabkan beban ekonomi dan sosial pada keluarga pasien ${ }^{6}$. Terdapat beberapa cara untuk menilai disabilitas yang disebabkan oleh stroke, di antaranya menggunakan National Institute of Health Stroke Scale (NIHSS) dan Barthel Index. NIHSS merupakan sistem scoring yang digunakan untuk menilai secara objektif disabilitas yang disebabkan oleh stroke secara klinis. Sedangkan Barthel Index menilai kemampuan aktivitas harian pasien pasca stroke.

Karena tingginya prevalensi serta angka disabilitas yang disebabkan oleh stroke, maka peneliti tertarik untuk melakukan penelitian tentang hubungan profil lipid dan kadar hs-CRP dengan outcome pasien stroke iskemik akut.

\section{METODE}

Penelitian observasional analitik ini dilaksanakan di laboratorium, poliklinik, serta bangsal sebuah rumah sakit di Kabupaten Sukoharjo pada bulan Mei sampai dengan Agustus 2019 dengan desain cross sectional. 
Subjek penelitian ditentukan secara consecutive sampling yaitu dengan mendata pasien dengan serangan stroke pertama yang sesuai dengan kriteria inklusi dan ekslusi sehingga memenuhi jumlah yang memenuhi syarat analisis. Penelitian ini telah dinyatakan layak etik oleh Komisi Etik Penelitian Kesehatan Universitas Sebelas Maret melalui Surat Keterangan Layak Etik nomor 118/UN27.06/KEPK/2019.

Kriteria inklusi pada penelitian ini adalah semua pasien yang terdiagnosa stroke iskemik dengan riwayat masuk ke rumah sakit dalam waktu 72 jam pasca onset serta pasien yang setuju mengikuti penelitian ini dibuktikan dengan menandatangani surat pernyataan persetujuan (informed consent) oleh dirinya sendiri ataupun oleh first-degree relative sebagaimana diatur dalam protokol etika penelitian. Peneliti mengekslusikan pasien dengan transient ischemic attack (TIA), recurrent ischemic stroke, serangan stroke kedua, stroke hemoragik, sindrom koroner akut, diabetes mellitus, gangguan hematologi (khususnya abnormalitas pemeriksaan fungsi hepar dan ginjal), serta neoplasma; pasien dengan riwayat masuk ke rumah sakit dalam waktu lebih dari 72 jam pasca onset; pasien dengan riwayat merokok dan mengonsumsi alcohol; pasien dengan tanda dan gejala klinis infeksi aktif, misalnya demam, batuk, sensasi terbakar saat miksi, serta pasien yang asimptomatik dengan bukti infeksi pada pemeriksaan penunjang seperti leukositosis pada pemeriksaan darah rutin, pus atau leukosit pada urinalisis, gambaran infiltrat pada foto polos thorax; serta pasien dengan riwayat penyakit inflamasi sebelumnya seperti rheumatoid arthritis dan Systemic Lupus Eritematosus (SLE) atau riwayat pemakaian steroid dan obat imunomodulator.

Dalam penelitian ini, kadar hs-CRP merupakan nilai yang diperoleh dari pemeriksaan laboratorium darah pasien berupa nilai serum hs-CRP yang dilakukan pada hari pasien masuk rumah sakit. Peneliti menggunakan reagen CRP Sekisui dalam penelitian ini. Sementara itu, profil lipid merupakan nilai yang diperoleh dari pemeriksaan laboratorium darah pasien berupa nilai serum high-density lipoprotein (HDL), low-density lipoprotein (LDL), trigliserida, dan kolesterol total yang dilakukan pada hari pasien masuk rumah sakit Outcome pasien stroke iskemik akut berupa skor NIHSS dan Barthel Index yang diukur pada hari ke-7 pasca onset stroke iskemik.

Data hasil uji penelitian dapat diuji dengan uji korelasi Pearson untuk mengetahui adanya hubungan antara profil lipid dan kadar hs-CRP dengan outcome pasien stroke iskemik akut yang diwujudkan dalam skor NIHSS dan Barthel Index karena data tersebut terdistribusi secara normal dengan uji Kolmogorov-Smirnov. Hasil dari uji korelasi Pearson dinyatakan dalam koefisien korelasi (r), yang akan mengukur arah dan kekuatan hubungan linier antara kedua variabel.

\section{HASIL}

Jumlah subjek dalam penelitian ini adalah 34 pasien yang menderita stroke iskemik akut terdiri dari 20 orang laki-laki $(58,8 \%)$ dan 14 orang perempuan $(41,2 \%)$. Usia rata-rata subjek penelitian adalah $57,12 \pm 9,80$ tahun dengan rentang usia 30 hingga 75 tahun. Jumlah tertinggi dari subjek penelitian berada pada kelompok usia 45-60 tahun, sebanyak 20 (dua puluh) orang pasien $(58,8 \%)$. Sementara itu, jumlah subjek penelitian terendah ditemukan pada kelompok usia antara 30-45 tahun, berjumlah empat orang $(11,8 \%)$.

Kadar kolesterol total subjek penelitian berkisar antara $79-311 \mathrm{mg} / \mathrm{dL}$ dengan rata-rata $185,56 \pm 46,81 \mathrm{mg} / \mathrm{dL}$. Kadar serum HDL subjek penelitian berkisar antara $13-48 \mathrm{mg} / \mathrm{dL}$ dengan rata-rata $31,71 \pm 9,24$ $\mathrm{mg} / \mathrm{dL}$. Kadar serum LDL subjek penelitian berkisar antara 29-193 mg/dL dengan rata-rata 
$125,26 \pm 37,11 \mathrm{mg} / \mathrm{dL}$. Kadar serum trigliserida subjek penelitian berkisar antara 73-419 $\mathrm{mg} / \mathrm{dL}$ dengan rata-rata $162,18 \pm 74,35 \mathrm{mg} / \mathrm{dL}$. Sementara itu, kadar serum hs-CRP subjek penelitian berkisar antara $1,05-25,65 \mathrm{mg} / \mathrm{L}$ dengan rata-rata 4,94 $\pm 5,02 \mathrm{mg} / \mathrm{L}$.

Pengukuran outcome subjek penelitian pada hari ketujuh perawatan di unit stroke dilakukan dengan penilaian NIHSS dan Barthel Index. Pada pemeriksaan NIHSS didapatkan hasil rentang skor antara 4-24 dan rata-rata $10,97 \pm 5,69$ dengan sebaran seperti terlihat pada gambar 1. Sementara itu, dari pengukuran Barthel Index subjek penelitian diperoleh rentang skor antara 20-70 dengan rata-rata $42,50 \pm 13,10$ dengan sebaran seperti terlihat pada gambar 2 .

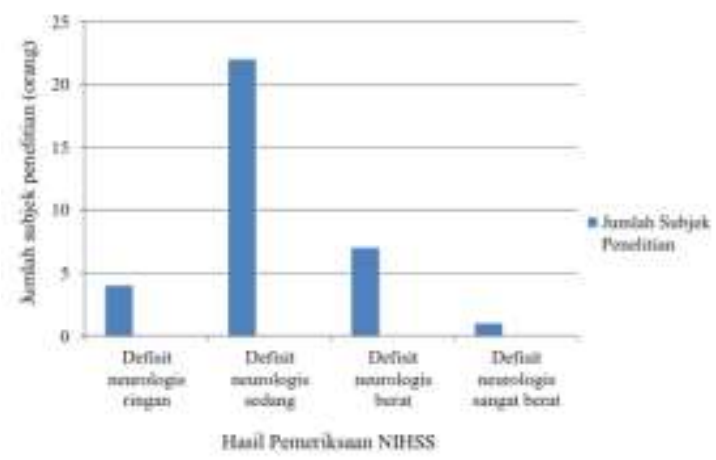

Gambar 1. Sebaran Hasil Pemeriksaan NIHSS

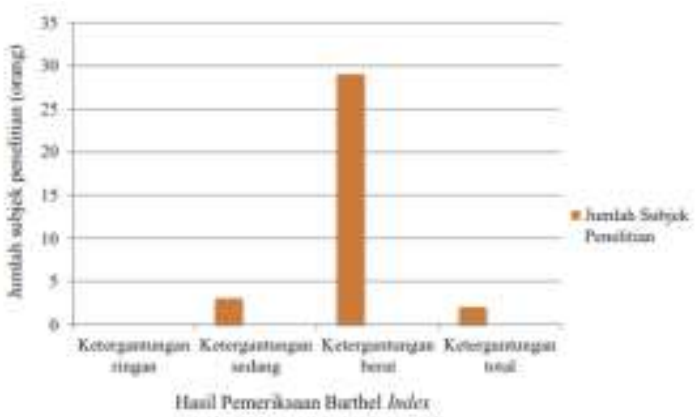

Gambar 2. Sebaran Hasil Pemeriksaan Barthel Index

Hasil uji One-Sample KolmogorovSmirnov dengan menggunakan SPSS 20.0 for Windows menunjukkan bahwa semua data terdistribusi normal $(\mathrm{p}>0,05)$. Korelasi profil lipid dengan NIHSS yang mencerminkan outcome stroke iskemik akut kemudian dinilai dengan melakukan uji korelasi Pearson untuk menentukan koefisien kontingensi. Hasil uji menunjukkan korelasi linier dengan kekuatan korelasi sedang dan signifikan secara statistik pada pemeriksaan kolesterol total, HDL, dan LDL seperti terlihat pada gambar 3 .

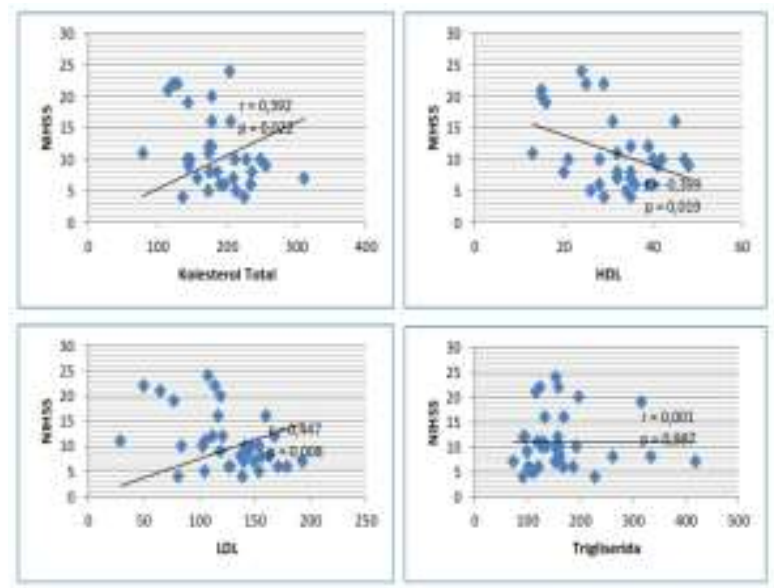

Gambar 3. Korelasi Profil Lipid dengan NIHSS

Selanjutnya, korelasi profil lipid dengan Barthel Index yang mencerminkan outcome stroke iskemik akut juga dinilai dengan melakukan uji korelasi Pearson untuk menentukan koefisien kontingensi. Hasil uji korelasi menunjukkan korelasi linier dengan kekuatan korelasi sedang, tetapi tidak signifikan secara statistik baik pada pemeriksaan kolesterol total, HDL, LDL, maupun trigliserida seperti terlihat pada gambar 4.

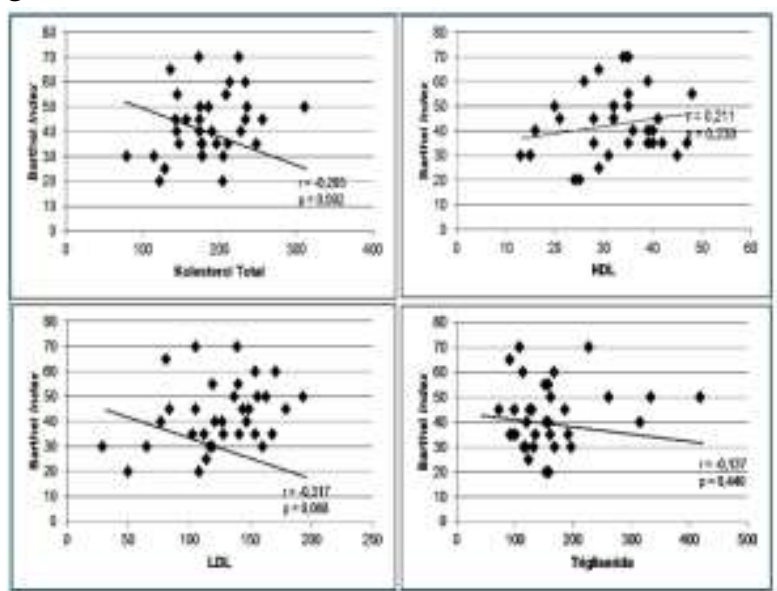

Gambar 4. Korelasi Profil Lipid dengan Barthel Index 
Setelah itu, korelasi hs-CRP dengan NIHSS dan Barthel Index sebagai outcome stroke iskemik akut dinilai juga dengan melakukan uji korelasi Pearson untuk menentukan koefisien kontingensi. Hasil uji korelasi menunjukkan korelasi linier sedang dan signifikan secara statistik seperti yang terlihat pada gambar 5 .

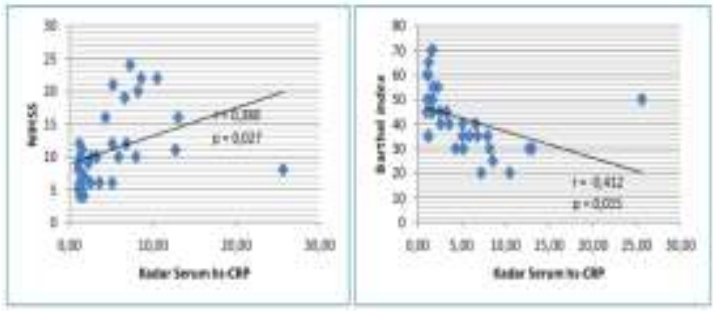

Gambar 5. Korelasi hs-CRP dengan NIHSS dan Barthel Index

Dari gambar 3 terlihat bahwa LDL memiliki korelasi yang paling signifikan secara statistik dengan outcome stroke iskemik akut. Selanjutnya, perbedaan antara nilai profil lipid dan hs-CRP sebagai prediktor prognosis outcome stroke iskemik akut dapat dinilai dengan membandingkan akurasi dari kedua tes (LDL dan hs-CRP yang paling signifikan secara statistik) dan kemudian menghitung nilai $\mathrm{Z}$ untuk mendapatkan signifikansi. Hasil analisis menunjukkan bahwa tidak ada perbedaan yang signifikan secara statistik terkait akurasi antara nilai profil lipid dan hs-CRP sebagai prediktor outcome stroke iskemik akut $(\mathrm{p}=0,6554)$ seperti yang terlihat pada Tabel 1 dan 2 .

Tabel 1. Korelasi nilai LDL dengan NIHSS sebagai outcome stroke iskemik akut Outcome (NIHSS) :

Defisit neurologis

Sedang Total Sangat Berat Ringan

\begin{tabular}{ccccc}
\hline LDL & $\begin{array}{l}\text { Risiko } \\
\text { tinggi } \\
\text { Risiko } \\
\text { rendah }\end{array}$ & 4 & 26 & 28 \\
\hline Total & 30 & 2 & 6 \\
\hline
\end{tabular}

Tabel 2. Korelasi nilai hs-CRP dengan Barthel Index sebagai outcome stroke iskemik akut

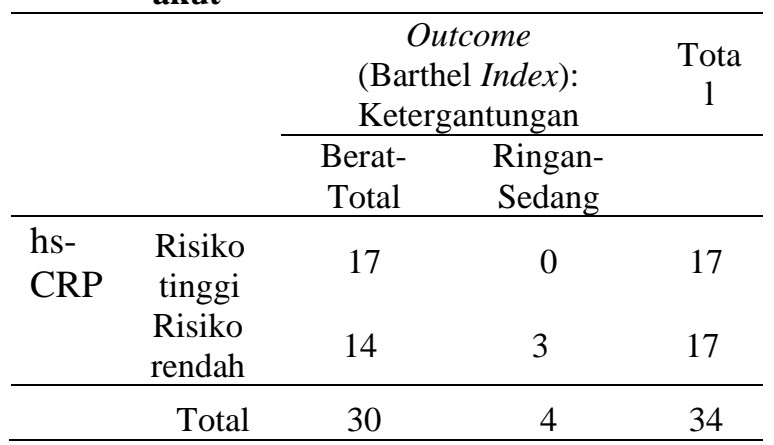

Nilai akurasi profil lipid yang digunakan untuk memprediksi outcome buruk dari stroke iskemik akut berasal dari tabel 1 diperoleh sebagai a+d/N=26+2/34= 28/34= $82,4 \%$. Nilai akurasi hs-CRP yang digunakan untuk memprediksi outcome buruk dari stroke iskemik akut berasal dari tabel 2 diperoleh sebagai a+d/N $=17+3 / 34=20 / 34=58,8 \%$.

Dalam analisis data penelitian ini, peneliti juga mencoba melakukan analisis korelasi Pearson antara profil lipid dan hsCRP untuk menentukan koefisien kontingensi. Hasil uji korelasi menunjukkan korelasi linier lemah dan tidak signifikan secara statistik seperti yang terlihat pada tabel 3 .

Tabel 3 Korelasi profil lipid dengan hs-CRP

\begin{tabular}{lcc}
\hline \multicolumn{1}{c}{ Variabel yang diuji } & $\mathrm{r}$ & $\mathrm{p}$ \\
\hline Kolesterol total - & 0,288 & 0,099 \\
hsCRP & & \\
HDL - hsCRP & $-0,154$ & 0,385 \\
LDL - hsCRP & 0,280 & 0,108 \\
Trigliserida - hsCRP & 0,059 & 0,742 \\
\hline
\end{tabular}

\section{PEMBAHASAN}

Berbagai penelitian menunjukkan bahwa hiperlipidemia dan inflamasi dapat mempercepat proses aterosklerosis dan memburuknya outcome stroke. Napoli et al. melaporkan bahwa kadar hs-CRP, biomarker inflamasi perifer, secara konsisten telah diamati memiliki keterkaitan dengan risiko kejadian serebrovaskular dan kardiovaskular serta secara sistematis meningkat dalam 
sirkulasi darah pasien setelah stroke akut ${ }^{7}$. Rost et al. menunjukkan bahwa peningkatan kadar hs-CRP secara independen dapat memprediksi risiko stroke dan transient ischemic attack (TIA) pada orang tua di masa depan ${ }^{8}$. Wakugawa et al. menemukan bahwa hs-CRP mungkin terlibat dalam setiap tahapan ini secara langsung dengan memengaruhi proses aktivasi komplemen, apoptosis, aktivasi sel vaskular, akumulasi lemak, dan trombosis 9 .

CRP, protein fase akut yang disintesis oleh hepatosit, dilepaskan dalam aliran darah sebagai respons terhadap inflamasi dan kerusakan jaringan. CRP merangsang sel endotel untuk menghasilkan berbagai molekul adhesi, seperti intracellular adhesion molecule-1, vascular cell adhesion molecule1, dan E-selectin ${ }^{10}$. Molekul-molekul ini memungkinkan migrasi sel mononuklear dan limfosit $\mathrm{T}$ ke dinding pembuluh darah dan memainkan peranan penting dalam pembentukan plak aterosklerotik ${ }^{11}$. CRP juga membantu pelepasan anion superoksida dan proses stimulasi aktivitas tissue factor. Selain itu, CRP juga menginduksi plasminogen activator inhibitor-1 (PAI-1), sebuah biomarker gangguan fibrinolisis dan aterosklerosis $^{12}$. Selain itu, CRP dapat meningkatkan kemungkinan lisisnya sel endotel dan erosi plak yang dapat memicu stroke iskemik akut atau sindrom koroner akut. Semuanya ini merupakan predisposisi aterosklerosis dalam sirkulasi otak dan jantung.

Sebagaimana hasil analisis data penelitian ini, kadar hs-CRP yang menunjukkan korelasi linear dengan tingkat keparahan atau outcome stroke iskemik akut mencerminkan bahwa nilai CRP dapat menjadi cerminan prognosis stroke iskemik akut. Sebagian besar penelitian telah menunjukkan kegunaan dari pengukuran CRP yang mengalami peningkatan dalam 12 dan 24 jam sejak serangan stroke ${ }^{13}$. Beberapa penelitian lain menunjukkan bahwa CRP sebagai faktor pro-aterogenik, memainkan kedua peranan pentingnya dalam regulasi peningkatan reseptor angiotensin II tipe 1 dan sebagai agen pro-inflamasi ${ }^{14}$. Ulasan oleh Napoli et al. menambahkan bahwa peningkatan kadar serum CRP merupakan penanda prognostik yang ada pada stroke iskemik, tetapi masih belum ada indikasi terapi yang pasti untuk menurunkan kadar CRP dalam rangka pencegahan sekunder penyakit serebrovaskular?

NIHSS dan Barthel Index digunakan dalam penelitian ini untuk mengevaluasi tingkat keparahan stroke. Banyak penelitian menunjukkan bahwa kedua instumen tersebut dapat membantu dalam prediksi outcome stroke ${ }^{15}$. Sebuah penelitian pada pasien stroke iskemik mengidentifikasi keparahan pasien stroke yang diukur dengan skor NIHSS dan Barthel Index saat masuk rumah sakit dan menjadi prediktor terkuat mortalitasnya tiga bulan kemudian ${ }^{16}$.

Dalam penelitian ini, hasil analisis korelasi profil lipid ditemukan lebih signifikan secara statistik terhadap NIHSS dibandingkan Barthel Index. Hal ini sejalan dengan penelitian Young et al. yang menyebutkan bahwa penggunaan NIHSS dalam penentuan prognosis stroke lebih sensitif daripada Barthel Index ${ }^{17}$. NIHSS adalah skala yang relevan digunakan dalam pengukuran prognosis pasien stroke fase akut karena lebih sensitif terhadap perubahan status neurologis pasien dan dapat mengukur efek terapi dibandingkan Barthel Index. Lyden dan Lau menyebutkan juga bahwa pemeriksaan Barthel Index terkadang dapat menimbulkan bias karena dipengaruhi oleh kondisi psikis pasien, misalnya pasien stroke yang mengalami depresi ringan akan lebih malas mengurus dirinya (makan, merapikan diri, mandi, dan sebagainya) dibandingkan pasien stroke yang tidak depresi ${ }^{18}$.

Hubungan antara kadar CRP yang tinggi dan tingkat keparahan atau buruknya outcome stroke dapat dijelaskan sebagai 
berikut. Aterosklerosis pembuluh darah otak merupakan gangguan inflamasi dengan protein reaktan fase akut yang diproduksi dalam beberapa jam pertama. Tingkat inflamasi yang ditentukan oleh peningkatan kadar CRP berkaitan erat dengan peningkatan risiko komplikasi vaskular $^{19}$. Ada kemungkinan juga bahwa CRP meningkat sebagai respon langsung terhadap tingkat cedera jaringan otak ${ }^{20}$.

Sebagai biomarker inflamasi, ada kemungkinan bahwa kadar CRP yang tinggi terkait dengan proses mendasar yang menyebabkan stroke lebih parah. Teori lain yang berhubungan adalah aktivasi faktor koagulasi oleh peningkatan kadar CRP memiliki peran penting dalam ekspresi tissue factor. Penelitian sebelumnya menunjukkan bahwa aktivasi faktor koagulasi pada pasien stroke meningkatkan mortalitas dan fibrinogen diduga memiliki peran yang penting dalam proses ini ${ }^{21}$. Penelitian lain juga telah menunjukkan bahwa CRP dapat berkontribusi dalam kerusakan otak sekunder setelah kejadian iskemia serebral fokal, mungkin melalui eksaserbasi yang dimediasi oleh komplemen akibat cedera jaringan ${ }^{22}$. Oleh karena itu, peningkatan kadar CRP setelah stroke tidak hanya merupakan konsekuensi dari infark otak, tetapi berkontribusi terhadap kerusakan iskemik juga.

Dislipidemia adalah salah satu faktor risiko utama untuk penyakit kardiovaskular dan serebrovaskular. Dalam penelitian ini, outcome pasien stroke iskemik berkorelasi secara signifikan dengan kadar serum kolesterol total (TC), HDL, dan LDL, tetapi tidak berkorelasi signifikan dengan kadar serum trigliserida (TG), yang sesuai dengan hasil penelitian sebelumnya ${ }^{23}$. Stroke iskemik biasanya disebabkan oleh penyumbatan tibatiba arteri yang membawa darah ke bagian otak. Ketika ada kelebihan kolesterol di dinding arteri, penyempitan arteri atau bahkan sebuah penyumbatan lengkap dapat terjadi di arteri. Di titik-titik sempit di arteri, pembekuan darah dapat terbentuk dan memblokir arteri atau memutuskan alirannya. Gorelick dan Mazzone menunjukkan hubungan antara kadar serum TC dan risiko stroke terutama berhubungan langsung dengan stroke iskemik ${ }^{24}$. Konishi et al. menemukan bahwa terdapat perbedaan efek kolesterol pada lokasi pembuluh darah yang berbeda, sehingga menyebabkan hubungan yang kompleks antara kadar kolesterol total serum dengan stroke ${ }^{25}$. Arteri karotis interna adalah lokasi yang paling umum untuk terjadinya aterosklerosis yang mengarah ke TIA atau stroke.

Rendahnya kadar serum HDL adalah faktor yang memperburuk outcome pada pasien dengan stroke iskemik akut pada penelitian ini. HDL merupakan sebuah antioksidan yang berperan penting dalam patogenesis stroke iskemik akut dengan menghambat oksidasi fosfolipid dan aktivitas LDL yang teroksidasi ${ }^{26}$. Penelitian sebelumnya membuktikan bahwa peningkatan kadar dan/atau fungsi HDL dan apolipoproteinnya dapat melindungi pembuluh darah utama dan mencegah cedera vaskuler. HDL berperan penting dalam perpindahan kolesterol dari jaringan perifer ke hati serta proses metabolisme kilomikron dan VLDL-kolesterol. HDL juga memengaruhi metabolisme dan transportasi fraksi lipid lainnya. Menariknya, sebuah penelitian tentang model tikus dengan stroke iskemik baru-baru ini menunjukkan efek menguntungkan dari HDL yang dimurnikan dan diberikan secara intravena dalam fase hiperakut stroke, yaitu dalam hal berkurangnya volume infark dan defisit neurologis ${ }^{27}$. Studi lain berupa pemberian niasin untuk meningkatkan kadar HDL pada tikus memberikan manfaat serupa dalam outcome fungsional ${ }^{28}$.

Kolesterol yang teroksidasi, khususnya LDL, memulai peradangan dan membentuk plak dalam dinding pembuluh 
darah yang menghambat aliran darah di arteri. LDL adalah faktor reaksi oksidasi yang lebih kuat dari TC dan HDL, dan pengendalian kadar LDL pada pasien dengan stroke iskemik akut selama perawatan di rumah sakit bisa meningkatkan prognosis mereka ${ }^{29}$. Penelitian ini mengungkapkan korelasi positif antara LDL dan outcome stroke iskemik. PedroBotet et al. dan Hachinski et al. juga menemukan korelasi positif antara kadar LDL dan risiko stroke iskemik ${ }^{30,31}$. Kar et al. membuktikan bahwa ada korelasi positif yang signifikan dari peningkatan LDL menuju proses aterosklerosis ${ }^{32}$. LDL adalah lipoprotein paling aterogenik. Lima puluh persen kolesterol dalam plasma ditemukan dalam bentuk LDL. LDL mengantarkan kolesterol ke jaringan perifer melalui sebuah reseptor LDL berafinitas tinggi khusus yang mengontrol serapan kolesterol oleh sel. Kelebihan jumlah LDL dalam darah akan menumpuk di dalam dinding pembuluh darah dan membuat darah lebih sulit untuk mengalir dengan bebas. Hal inilah yang meningkatkan risiko seseorang untuk terkena stroke ${ }^{33}$.

Sementara itu, TG tidak berkorelasi signifikan secara statistik dalam penelitian ini. Beberapa alasan dapat menjelaskan hubungan ini. Pertama, hubungan antara kadar serum trigliserida yang rendah dengan outcome stroke akut seolah-olah menentang proses inflamasi pada hubungan ini. Butterworth et al. menunjukkan bahwa konsentrasi trigliserida tidak berubah pada minggu pertama setelah stroke iskemik; sebaliknya, penelitian mereka mencatat bahwa kolesterol total dan LDL turun setelah serangan stroke dan mencapai signifikansi dalam satu minggu pertama pasca serangan ${ }^{34}$. Kedua, pada pemeriksaan kadar trigliserida serum total puasa, mayoritas trigliserida yang diukur bersirkulasi dalam bentuk partikel dengan densitas lipoprotein yang sangat rendah atau VLDL (very low-density lipoprotein) yang juga membawa kolesterol ${ }^{35}$. Ketiga, hubungan kadar serum trigliserida yang rendah dengan peningkatan mortalitas setelah stroke iskemik sebenarnya konsisten dengan elemen kekurangan gizi. Penurunan trigliserida yang signifikan dapat dipengaruhi oleh pembatasan asupan energi, terlepas dari penurunan berat badan. Selain itu, ada banyak data untuk menunjukkan pembatasan energi itu dapat mengurangi trigliserida jauh lebih banyak daripada kolesterol ${ }^{36}$.

Penelitian sebelumnya menyebutkan bahwa ada perbedaan profil lipid berdasarkan jenis kelamin ${ }^{37}$. Beberapa penelitian terdahulu menyebutkan bahwa pada masa transisi baik pre-menopause maupun pasca-menopause pada wanita sering timbul sindrom metabolik dan peningkatan kadar serum trigliserida hampir $16 \%$ dari nilai normal ${ }^{38}$. Analisis dari National Health and Nutrition Examination Survey (NHANES) selama lebih dari 4 dekade mengungkapkan bahwa perbedaan kadar trigliserida antara pria dan wanita mulai berkurang pada kelompok usia 50-59 tahun dan setelah usia 60 tahun ke atas, wanita memiliki kadar trigliserida yang lebih tinggi daripada pria $^{39}$. Sementara itu, Devaraj et al. dan Wakugawa et al. menemukan bahwa peningkatan kadar serum CRP adalah faktor risiko independen untuk stroke iskemik masa depan hanya pada pria dan bukan pada wanita $^{9,40}$. Estrogen endogen telah terbukti mencegah perkembangan aterosklerosis, dan memiliki efek anti-inflamasi pada wanita. Namun, Muir et al. tidak menemukan hubungan antara jenis kelamin dan peningkatan kadar CRP pada pasien stroke iskemik akut ${ }^{41}$.

Dalam penelitian ini, keterbatasan jumlah subjek yang memenuhi kriteria inklusi dan kriteria ekslusi menjadi alasan belum dilakukannya analisis kovariat terhadap jenis kelamin dan umur. Hal ini mungkin menjadi penyebab hasil koefisien korelasi yang didapatkan belum cukup kuat, walaupun sudah signifikan secara statistik. Studi kohort prospektif dengan jumlah sampel yang lebih besar yang menilai hubungan profil lipid dan 
kadar CRP terhadap outxome stroke masih diperlukan. Analisis longitudinal dari populasi ini dapat memberikan pengetahuan lebih lanjut di bidang neurologi perihal kemungkinan memprediksi outcome pasien stroke iskemik akut dan menentukan target terapi dengan menggunakan biomarker inflamasi perifer atau profil lipid di masa depan.

\section{KESIMPULAN}

Hasil penelitian dan uji statistik data yang dilakukan menunjukkan bahwa ada hubungan antara profil lipid dan kadar hsCRP dengan outcome pasien stroke iskemik akut. Profil lipid dan hs-CRP dapat digunakan sebagai prediktor prognosis outcome stroke iskemik akut.

\section{UCAPAN TERIMA KASIH}

Penulis mengucapkan terima kasih kepada Direktur dan Manajemen Rumah Sakit Universitas Sebelas Maret serta Bagian Medical Education and Research Centre Rumah Sakit Universitas Sebelas Maret yang telah membantu terlaksananya penelitian ini.

\section{DAFTAR PUSTAKA}

1. Kustiowati, E. 2003. Trombosis di bidang neurologi: stroke iskemik. Semarang: Bagian Neurologi Universitas Diponegoro.

2. Kementerian Kesehatan Republik Indonesia. 2018. Laporan Hasil Riset Kesehatan Dasar Indonesia Tahun 2018. Jakarta: Kementerian Kesehatan Republik Indonesia.

3. Dinata CA, Safrita Y, Sastri S. 2013. Gambaran Faktor Resiko dan Tipe Stroke pada Pasien Rawat Inap di Bagian Penyakit Dalam RSUD Kabupaten Solok Selatan Periode 1 Januari 2010-31 Juni 2012. Jurnal Kesehatan Andalas; 2(2):16-22.

4. Aguiar FJB, Ferreira-Junior M, Sales MM, Cruz-Neto LM, Fonseca LAM, Sumita NM, et al. 2013. C-reactive Protein: Clinical Applications and Proposals for a Rational Use. Associacao Medica Brasileira; 59(1):85-92.
5. Zhou Y, Han W, Gong D, Man C, Fan Y. 2015. Hs-CRP in Stroke: A Meta Analysis. Clinica Chemica Act.; 26(1):15-24.

6. Misbach J, Ali W. 2001. Stroke in Indonesia: a first large prospective hospital-based study of acute stroke in 28 hospitals in Indonesia. Journal of Clinical Neuroscience; 8(3):245249.

7. Napoli M, Papa F, Bocola V. 2001. Prognostic influence of increased C-reactive protein and fibrinogen levels in ischemic stroke. Stroke; 32(1):133-138.

8. Rost NS, Wolf PA, Kase CS, Kelly-Hayes M, Silbershatz H, Massaro JM, et al. 2001. Plasma concentration of C-reactive protein and risk of ischemic stroke and transient ischemic attack: the Framingham study. Stroke; 32(11):2575-2579.

9. Wakugawa Y, Kiyohara Y, Tanizaki Y, Kubo M, Ninomiya T, Hata J, et al. 2006. Creactive protein and risk of first-ever ischemic and hemorrhagic stroke in a general Japanese population: the Hisayama Study. Stroke; 37(1):27-32

10. Sabatine MS, Morrow DA, Jablonski KA, Rice MM, Warnica JW, Domanski MJ, et al. 2007. Prognostic significance of the Centers for Disease Control/American Heart Association high-sensitivity C-reactive protein cut points for cardiovascular and other outcomes in patients with stable coronary artery disease. Circulation; 115(12): 1528-1536.

11. Hulthe J, Wikstrand J, Mattsson-Hulten L, Fagerberg B. 2002. Circulating ICAM-1 (intercellular cell-adhesion molecule 1) is associated with early stages of atherosclerosis development and with inflammatory cytokines in healthy 58-year-old men: the Atherosclerosis and Insulin Resistance (AIR) study. Clin Sci (Lond); 103(2):123-129.

12. Chen C, Nan B, Lin P, Yao Q. 2008. Creactive protein increases plasminogen activator inhibitor-1 expression in human endothelial cells. Thromb Res; 122(1):125133.

13. Ridker PM, Cook N. 2004. Clinical usefulness of very high and very low levels of C-reactive protein across the full range of Framingham risk scores. Circulation; 109:1955-1959.

14. Dandona P. 2008. Effects of antidiabetic and antihyperlipidemic agents on C-reactive protein. Mayo Clin Proc; 83:333-342. 
15. Dhamoon MS, Moon YP, Paik MC, BodenAlbala B, Rundek T, Sacco RL, et al. 2009. Long-term functional recovery after first ischemic stroke: the Northern Manhattan Study. Stroke; 40(8):2805-2811.

16. Chang $\mathrm{KC}$, Tseng MC, Tan TY, Liou CW. 2006. Predicting 3-month mortality among patients hospitalized for first-ever acute ischemic stroke. J Formos Med Assoc; 105(4):310-317.

17. Young FB, Weir CJ, Lees KR. 2005. GAIN International Trial Steering Committee and Investigators. Comparison of the National Institutes of Health Stroke Scale with disability outcome measures in acute stroke trials. Stroke; 36:2187-2192.

18. Lyden PD, Lau GT. 1991. A critical appraisal of stroke evaluation and rating scales. Stroke; 22:1345-1352.

19. Bahadursingh S, Beharry K, Maharaj K, Mootoo C, Sharma P, Singh J, et al. 2009. Creactive protein: adjunct to cardiovascular risk assessment. West Indian Med J; 58(6):551-555.

20. Audebert HJ, Rott MM, Eck T, Haberl RL. 2004. Systemic inflammatory response depends on initial stroke severity but is attenuated by successful thrombolysis. Stroke; 35(9):2128-2133.

21. Feinberg WM, Erickson LP, Bruck D, Kittelson J. 1996. Hemostatic markers in acute ischemic stroke. Association with stroke type,severity, and outcome. Stroke; 27(8):1296-300.

22. Pepys MB, Hirschfield GM, Tennent GA, Gallimore JR, Kahan MC, Bellotti V, et al. 2006. Targeting C-reactive protein for the treatment of cardiovascular disease. Nature; 440(7):1217-1221.

23. Amarenco P, Labreuche J. 2009. Lipid management in the prevention of stroke: review and updated meta-analysis of statins for stroke prevention. Lancet Neurol; 8:453463.

24. Gorelick PB, Mazzone T. Plasma lipids and stroke. 1999. J Cardiovasc Risk; 6(4):217221.

25. Konishi $\mathbf{M}$, Iso $\mathrm{H}$, Komachi $\mathrm{Y}$, Iida $\mathrm{M}$, Shimamoto T, Jacobs DR Jr., et al. 1993. Associations of serum total cholesterol, different types of stroke, and stenosis distribution of cerebral arteries. The Akita Pathology Study. Stroke; 24(7):954-964.

26. Navab M, Berliner JA, Subbanagounder G. 2001. HDL and the inflammatory response induced by LDL-derived oxidized phospholipids. Arterioscler Thromb Vasc Biol; 21:481-488.

27. Lapergue B, Moreno JA, Dang BQ. 2010. Protective effect of high-density lipoproteinbased therapy in a model of embolic stroke. Stroke; 41:1536-1542.

28. Chen J, Cui X, Zacharek A. 2007. Niaspan increases angiogenesis and improves functional recovery after stroke. Ann Neurol; 7:49-58.

29. Adibhatla RM, Hatcher JF. 2010. Lipid oxidation and peroxidation in CNS health and disease: from molecular mechanisms to therapeutic opportunities. Antioxid Redox Signal; 12:125-169.

30. Pedro-Botet J, Senti M, Nogues X, RubiesPrat J, Roquer J, D'Olhaberriague L, et al. 1992. Lipoprotein and apolipoprotein profile in men with ischemic stroke. Role of lipoprotein (a), triglyceride-rich lipoproteins, and apolipoprotein E polymorphism. Stroke; 23(11):1556-1562.

31. Hachinski V, Graffagnino C, Beaudry $M$, Bernier G, Buck C, Donner A, et al. 1996. Lipids and stroke: a paradox resolved. Arch Neurol; 53(4):303-308.

32. Kar AM, Garg RK, Gaur SPS. 1993. Serum Lipids and Stroke. Neurol India; 41(1):1-5.

33. Willey JZ, Xu Q, Boden-Albala B, Paik MC, Moon YP, Sacco RL, et al. 2009. Lipid profile components and risk of ischemic stroke: the Northern Manhattan Study (NOMAS). Arch Neurol; 66(11):1400-1406.

34. Butterworth RJ, Marshall WJ, Bath PMW. 1997. Changes in serum lipid measurements following acute ischaemic stroke. Cerebrovasc Dis; 7:10-13.

35. Tan CE, Squires L, Caslake MJ. 1995. Relationship between very low and low density lipoprotein subfractions in normolipaemic men and women. Arterioscler Thromb Vasc Biol; 13:1839-1848.

36. Kempf M: Effect of nutrition on combined hyperlipidaemia. 1997. Ann Endocrinol; 58:292-296.

37. Bittner V. 2008. Impact of Gender and Life Cycle on Triglyceride Levels. Omaha Nebraska: Medscape Family Medicine (CME).

38. Poehlman ET, Toth MJ, Ades PA, and Rosen CJ. 1997. Menopause-associated changes in plasma lipids, insulin-like growth factor I and blood pressure: a longitudinal study. 
Putra et al., Hubungan Profil Lipid dan Kadar High-Sensitivity C-Reactive Protein dengan Outcome Pasien Stroke Iskemik Akut

European Journal of Clinical Investigation; 27(4):322-326.

39. Carroll MD, Lacher DA, Sorlie PD. 2005. Trends in serum lipids and lipoproteins of adults, 1960-2002. Journal of the American Medical Association; 294(14):1773-1781.

40. Devaraj S, Du Clos TW, Jialal I. 2005. Binding and internalization of C-reactive protein by Fcgamma receptors on human aortic endothelial cells mediates biological effects. Arterioscler Thromb Vasc Biol; 25(7):1359-1363.

41. Muir KW, Weir CJ, Alwan W, Squire IB, Lees KR. 1999. C-reactive protein and outcome after ischemic stroke. Stroke; 30(5): 981-985. 